ISSN : $2302-1590$

E-ISSN: $2460-190 \mathrm{X}$

ECONOMICA

Journal of Economic and Economic Education Vol.3 No.1 (79 - 88)

\title{
RESPON LINGKUNGAN BELANJA SEBAGAI STIMULUS PEMBELIAN TIDAK BERENCANA PADA MINI MARKET MAMI MART PAINAN
}

\author{
Mareta Kemala Sari \\ Dosen Program Studi Pendidikan Ekonomi STKIP- PGRI Sumbar \\ Jl. Gunung Pangilun No.1, Padang Sumatera Barat \\ Email : maretakemalasari@gmail.com \\ submited: 14.06 .22 reviewed:14.07.21 accepted: 14.10 .30 \\ http://dx.doi.org/10.22202/economica.2014.v3.i1.238
}

\begin{abstract}
Research berencamna not purchase the mini market mart mom visits from customer response to environmental spending as a stimulus, a customer case study on mini market mart mom Painan. Research using response variables shopping environment consisting of Pleasure, Arousal, Dominance.sebagai mediator variable, hedonic shopping value, utilitarian shopping value, resources expenditure on the purchase was not planned (Impulse Buying). Data were collected using questionnaires distributed during the 2 weeks to the respondents who never berbelanjadi mini market. The study population is that they all are a mini market mommy mart customers aged 18-55 years and have never shopped with a minimum of 2 times the transaction, the methods used by the descriptive analysis, and processing research model with smartPLS program. Mengunggapkan research results that the response variable dominance shopping environment positive effect on resources expenditure. Shopping environment arousal response variable positive effect on resources expenditure. Also revealed that spending resources poengalaman variable expenditure not a mediator between the response variable shopping environment and other variables shopping experience, as well as the negative effect on the purchase was not planned. But the expenditure of resources affect the shopping experience more variables such as the hedonic shopping value, utilitarian shopping value, resources expenditure
\end{abstract}

\section{Abstrak}

Penelitian pembelian tidak berencamna pada mini market mami mart dilihat dari respon pelanggan terhadap lingkungan belanja sebagai stimulus, suatu studi kasus pada pelanggan mini market mami mart Painan. Penelitian menggunakan variabel respon lingkungan belanja yang terdiri dari Pleasure, Arousal, Dominance.sebagai variabel mediator, hedonic shopping value, utilitarian shopping value, resources expenditure terhadap pembelian tidak berencana (Impulse Buying). Data dikumpulkan dengan menggunakan kuesioner yang disebar selama 2 minggu kepada responden yang pernah berbelanjadi mini market. Populasi penelitian adalah mereka semua yang merupakan pelanggan mini market mami mart yang berusia 18-55 tahun dan telah pernah berbelanja dengan transaksi minimal 2 kali, metode yang digunakan dengan analisis deskriptif, dan pengolahan model penelitian dengan program smartPLS. Hasil penelitian mengunggapkan bahwa variabel respon lingkungan belanja dominance berpengaruh positif terhadap resources expenditure. Variabel respon lingkungan belanja arousal berpengaruh positif terhadap resources expenditure. Terungkap juga bahwa variabel poengalaman belanja resources expenditure Tidak merupakan variabel mediator antara respon lingkungan belanja dan variabel pengalaman belanja lainnya, serta berpengaruh negatif terhadap pembelian tidak berencana. Namun resources expenditure berpengaruh dengan variabel pengalaman belanja lainnya seperti hedonic shopping value, utilitarian shopping value, resources expenditure

Keyword: Shopping environment, the purchase is not planned

C2014 Prodi Pendidikan Ekonomi STKIP PGRI, Padang 


\section{PENDAHULUAN}

telah $\begin{gathered}\text { Kemajuan di bidang perekonomian } \\ \text { banyak membawa akibat }\end{gathered}$ perkembangan yang pesat dalam bidang usaha. Sejalan dengan itu banyak bermunculan perusahaan dagang yang bergerak di bidang perdagangan eceran yang berbentuk toko, mini market, depertemen store, pasar swalayan dan lainlain. Hal ini tentu akan menimbulkan persaingan di antara bidang perdagangan eceran terebut. Untuk memenangkan persaingan perusahaan memanfaatkan peluang bisnis yang ada dan berusaha untuk menerapkan strategi pemasaran yang tepat dalam rangka untuk menguasai pasar. Syarat yang harus dipenuhi oleh perusahaan agar sukses dalam persaingan adalah berusaha untuk menciptakan dan mempertahankan pelanggan dengan senantiasa menciptakan superior value yang diinginkan konsumen dalam rangka memenuhi kepuasannya.

Dengan meningkatnya kebutuhan hidup, salah satu usaha perdagangan yang keberadaannya sangat dibutuhkan oleh masyarakatpada saat ini adalah usaha di bidang pertokoan. Perilaku konsumen merupakan hal yang sangat penting, guna menarik dan mempertahankan kelangsungan hidup usahanya, karena memahami perilaku konsumen dapat memberikan petunjuk mengenai siapa konsumen, bagaimana cara memenuhi selera konsumen agar perusahan dapat memberikan kepuasan kepada konsumennya.

Pelanggan dapat menjadi asset perusahaan yang paling berharga, sehingga perusahaan perlu menciptakan sekaligus menjaga ekuitas tersebut (Ambier, et.all: 2002 dalam sunarto 2004)

Perusahaan membutuhkan informasi pelanggan yang efektif dari dalam ruang toko dan menjadi stimulus terhadap perilaku pembelian produk secara umum. Pengecer membutuhkan informasi tersebut untuk menentukan efisiensi penggunaan sumber daya yang dirancang dalam menambah penjualan dan juga dapat mendifferensiasi ruang toko sebagai salah satu strategi bersaing terhadap pesaing. Kendala yang sering dihadapi oleh pihak manajemen toko dalam membuat dan menerapkan strategi pemasarannya adalah kurangnya informasi yang akurat mengenai perilaku konsumen, sehingga manajemen perlu mencari dan mengumpulkan informasi tentang konsumen agar dapat menarik dan mempertahankan pembeli untuk menggunakan produk yang di pasarkannya.

Saat ini berbagai macam pusat perbelanjaan eceran mulai bermunculan dengan bermacam bentuk dan ukuran. Menurut Kotler dan Kelller (2009: 141) pengecer dibagi atas toko barang khusus, depertemen store, pasar swalayan, toko kelontong, toko diskon, pengecer off-price, superstore, ruang pamer katalog. Salah satu jenis pengecer adalah toko diskon yakni toko dengan barang standar atau barang khusus, harga murah, margin rendah, volume tinggi.Pengecer jenis ini banyak di temui di sumatera barat.

Beberapa contoh bentuk pusat perbelanjaan ecerannya misalnya mini market dan toserba. Dengan semakin banyak mini market yang ditemui di berbagai tempat, maka keberadannya di tengah tengah masyarakat menjadi semakin penting saat ini. Hal ini disebabkan karena adanya perubahancara pandang konsumen terhadap mini market itu sendiri. Terkadang konsumen berbelanja tidak hanya untuk mencari kebutuhan mereka akan produk atau merek tertentu, tetapi juga untuk menghabiskan waktu senggang di sore atau malam hari.

Tidak sedikit perilaku rekreasi pada pusat perbelanjaan eceran ini menimbulkan pembelian diluar rencana (Impulse Buying) akibat adanya rangsangan lingkungan belanja (Shopping Environment) dengan cara mempengaruhi 
konsumen yang tidak tertarik menjadi tertarik berbelanja. Implikasi dari lingkungan belanja terhadap perilaku pembelian mendukung asumsi bahwa jasa layanan fisik menyediakan lingkungan yang mempengaruhi perilaku konsumen, dihubungkan dengan karakteristik lingkungan konsumsi fisik (Kenyamanan toko, Lay Out, warna, kebersihan ruangan).lingkungan belanja mampu mempengaruhi emosi konsumen dari yang tadinya tidak berencana membeli menjadi tertarik untuk membeli.

Secara spesifik, dari penelitian sebelumnya mengenai suasana sebuah lingkungan belanja serta lingkungan retail dapat mengubah emosi konsumen (Donovan dan Rossiter, 1982). Perubahan emosi mengubah suasana hati konsumen yang mempengaruhi perilaku pembelian dan evaluasi tempat belanja (Babin, Darden dan Griffin, 1984: Dawson, Bloch dan Ridgway, 1990< Gardner 1985). Toko dapat menawarkan suasana atau lingkungan yang dapat mempengaruhi pola perilaku keputusan konsumen (Parasuraman, 1994). Lingkungan belanja dan suasana hati dapat mempengaruhi konsumen untuk melakukan pembelian tidaak berenccana. Psikolog lingkungan menyatakan individu dapat bereaksi dalam dua perilaku yakni mendekat atau menghindar (Approach and Avoidance) (Mehrabian and Russel, 1974). Perilaku mendekat meliputi perilaku positif yang diarahkan pada tempat tertentu, seperti keinginan untuk tinggal, menyelidiki, bekerja dan bergabung sedangkan perilaku menghindar mencerminkan kebalikan dari perilaku positif.

Mami mart adalah salah satu jenis toko kelontong di daerah kabupaten pesisir selatan. Tepatnya di kota painan. Mini market ini juga merupakan mini market kedua dari total dua mini market yang muncul. Menyediakan berbagai produk consumer goods, seperti minuman dan makanan ringan, produk kecantikan, produk perlengkapan rumah tangga, perlengkapan listrik dan perlengkapan bayi dengan berbagai merek untuk memanjakan konsumen dalam memilih. Sebagai follower tentu mini market ini berusaha mendapatkan posisi sebagai market leader di pasar. Dengan menyedepankan layanan. Suasana belanja yang ditemani alunan musik dan disesuaikan dengan waktu, aroma khas mawar dari setiap lorong serta pencahayaan yang terang dan ventilasi yang memungkinkan cahaya masuk, ruangan ber AC.

Pada awal pembukaan mini market ini, berdasarkan pengamatan konsumen ragu untuk berbelanja dikarenakan rasa khawatir harga yang tinggi yang dibebankan kepada produk untuk membalas layanan dan suasana belanja yang ditawarkan. Karyawan sebagai sahabat belanja konsumen di tuntut tidak hanya melayani permintaan dan pembayaran atas barang yang dibeli tetapi juga dituntut untuk bekerja secara terampil, bersikap ramah dengan menghapal nama konsumen yang berkunjung, menyapa konsumen dengan nama panggilannya dan memperhatikan pola belanja konsumen setiap kali berkunjung. Karyawan juga di tuntut pihak manajemen untuk tahu jenis, manfaat serta penggunaan produk. Sehingga secara tidak langsung karyawan berperan sebagai sales representative dari semua kategori produk yang ada.

Pengamatan peneliti yang juga merupakan pihak manajemen dari mini market ini mendapat bahwa tidak semua konsumen merasa nyamandengan lingkungan belanja. Masih terlihat konsumen yang tidak terdorong untuk menelusuri lorong-lorongyang adadan enggan untuk mengamati produk yang telah didisplay sedemikian rapi. Mereka masih enggan untuk berputar melainkan hanya menanyakan produk yang mereka cari kepada kasir, mereka tidak mau mengambil sendiri apa yang ia cari. Ini 
tidak sesuai dengan pola mini market yang menuntut konsumen untuk melayani sendiri apa yang dibituhkan. Dengan keengganan konsumen untuk berputar dan mencari sendiri apa yang ia inginkan membuat pembelian tidak berencana yang diinginkan terjadi oleh pihak manajemen menjadi kecil.

Pihak manajemen berupaya selalu menciptakan lingkungan belanja yang membuat konsumen betah untuk mengitari setiap lorong belanja. Ini dilakukan dengan mengubah lay out, membuat tema-tema dihari penting. Dari pantauan CCTV manajemen, pemilik convinience shopping seperti mini market masih menemukan adanya konsumen yang langsung keluar ketika menanyakan produk yang ia butuhkan saat itu kosong, target manajemen dengan lingkungan belanja yang menyenangkan membuat konsumen untuk tertarik masuk lebih jauh mengitari setiaap lorong, menyitari lorong yang ada sambil menghabiskan waktu di sore hingga malam hari. Sehingga kekososngan produk tidak lagi membuat konsumen kecewa, karena terobati oleh reminder impulsingdimana produk-produk yang sebelumnya tidak adadiingatan konsumen namun setelah mengitari tempat belanja konsumen teringat akan kebutuhannya. Menurut Utami (2010:51) reminder impulsing merupakan pembelian yang terjadi ketika konsumen melaihat produk atau merek tertentu didalam toko dan teringat bahwa produk atau merek tersebut mereka butuhkan.

\section{"RESPON DIMENSI LINGKUNGAN BELANJA SEBAGAI STIMULUS PEMBELIAN TIDAK BERENCANA PADA MINI MARKET MAMI MART" Rumusan masalah}

Berdasarkan latar belakang, maka dapat ditarik rumusan masalah sebagai berikut:

1. Apakah respon lingkungan belanja konsumen berpengaruh langsung terhadap pengalaman belanja
2. Apakah tingkat pengeluaran sumber daya konsumen (Resources Expenditure) merupakan variabel mediator antara respon lingkungn belanja terhadap pembelian tidak berencana.

3. Apakah respon lingkungan belanja berpengaruh langsung terhadap pembelian tidak berencana.

4. Apakah respon lingkungsn belanja dan pengalaman belanja melalui tingkat pengeluaran sumber daya konsumen (Resources Expenditure)berpengaruh langsung terhadap pembelian tidak berencana.

\section{Tujuan Penelitian.}

Penelitian ini bertujuan untuk mengetahui :

1. Pengaruh langsung respon lingkungan belanja konsumen terhadap pengalaman belanja Konsumen mini market "Mami Mart" Painan.

2. Pengaruh tingkat pengeluaran sumber daya konsumen (Resources $2 q$ Expenditure) Sebagai variabel mediator antara respon lingkungn belanja terhadap pembelian tidak berencana.

3. Pengaruh langsung respon lingkungan belanja terhadap pembelian tidak berencana.

4. Pengaruh respon lingkungsn belanja dan pengalaman belanja melalui tingkat pengeluaran sumber daya konsumen (Resources Expenditure) terhadap pembelian tidak berencana.

\section{METODE PENELITIAN}

Penelitian ini merupakan penelitian Konklusif-Deskriptif yang bertujuan menguji hipotesis atau hubungan spesifik tertentu sehingga informasi yang dibutuhkan direncanakn secara terstruktur dan jelas serta mendeskripsikan peristiwa atau kejadian dan menemukan ada tidaknya pengaruh variabel yang diteliti. Populasi penelitian merupakan seluruh konsumen yang pernah berbelanja pada mini market mami mart dengan tekhnik 
pengambilan sampel non probability sampling dan metode convinience Sampling dalam menentukan ukuran sampel digunakan pendapat Hair (1998:166) yakni 5-20 kali variabel penelitian dimana 20 kali 3 variabel yakni sebanyak $60 \quad$ Responden.Definisi operational penelitian dengan variabel Lingkungan Belanja, Pengalaman Belanja dan pembelian tidak berencana dapat dilihat lebih jelas pada tabel berikut

Tabel 1. Definisi Operational Penelitian.

\begin{tabular}{|c|c|c|}
\hline Variabel & Sub Dimensi & Ukuran \\
\hline \multicolumn{3}{|l|}{ Lingkungan Belanja } \\
\hline A. Pleasure & 1. Nyaman & 1. Tingkat kenyamanan \\
\hline $\begin{array}{lll}\text { Perasaan } & \text { Individu } & \text { saat } \\
\text { berada di } & & \end{array}$ & 2. Bahagia & 2. Tingkat kebahagiaan \\
\hline lingkungan belanja & 3. $\quad$ Puas & 3. Tingkat Kepuasan \\
\hline B. Arousal & 1. Tertarik & 1. Tingkat Ketertarikan \\
\hline $\begin{array}{l}\text { Tingkat aktif, Siaga } \\
\text { tertarik konsumen } \\
\text { lingkungan Belanja }\end{array}$ & 2. Aktif & 2. Tingkat Keaktifan \\
\hline \multicolumn{3}{|l|}{ C. Dominance } \\
\hline $\begin{array}{l}\text { Laporan responden yang } \\
\text { merasa dikendalikan }\end{array}$ & $\begin{array}{llr}\text { 1. } & \text { Perasaan } & \text { yang } \\
\text { dilontarkan } & \text { saat } \\
\text { dikendalikan } & \end{array}$ & $\begin{array}{lr}\text { 1. Tingkat } & \text { terpengaruh } \\
\text { dengan } & \text { lingkungan } \\
\text { belanja } & \end{array}$ \\
\hline \multicolumn{3}{|l|}{ Pengalaman Belanja } \\
\hline A. Hedonic Shopping Value & $\begin{array}{l}\text { 1. Kesenangan Panca } \\
\text { Indera }\end{array}$ & 1. Tingkat Kesenangan \\
\hline \multirow{2}{*}{$\begin{array}{l}\text { Pengalaman Belanja terkait } \\
\text { dengan khayalan, Perasaan } \\
\text { Dan Pengalaman dengan } \\
\text { Produk }\end{array}$} & 2. Nilai Emosional & 2. $\quad$ Tingkat Emosional \\
\hline & $\begin{array}{ll}\text { 3. Hiburan Potensial } \\
\text { Belanja }\end{array}$ & 3. Tingkat Keterhiburan \\
\hline B. Utilitarian Shopping Value & $\begin{array}{l}\text { 1. Manfaat dari } \\
\text { produk belanja }\end{array}$ & 1. Tingkat Kegunaan \\
\hline \multirow[t]{2}{*}{ C. Resources Expenditure } & 1. Waktu Pengeluaran & 1. Tingkat Efisiensi Waktu \\
\hline & 2. Pengeluaran & 2. Tingkat Harga. \\
\hline
\end{tabular}

\section{Pembelian Tak Berencana}

\begin{tabular}{|c|c|}
\hline 1. Tidak direncanakan & $\begin{array}{l}\text { Intensitas melakukan } \\
\text { pembelian tak berencana }\end{array}$ \\
\hline $\begin{array}{ll}\text { 2. } & \text { Terpengaruh } \\
\text { Promosi } \\
\text { Pramuniaga }\end{array}$ & 2. Tingkat Terpengaruh \\
\hline
\end{tabular}

\section{Instrumen yang digunakan}

dalam penelitian ini berbentuk angket pertanyaan tertutup dengan penggunaan skala likert lima tingkatan dimulai dari sangat setuju yang bernilai 5 point dan sangat tidak setuju yang bernilai 1 Point untuk pertanyaan positif. 
Analisa yang digunakan dalam menguji model penelitian dan hipotesis adalah analisa Struktural Equation Modeling (SEM) dengan bantuan program aplikasi smartPLS. SEM dapat ditunjukan sebagai kombinasi dari analisis faktor, analisis regresi dan analisis Path. Diagram path atau diagram lintasan merupakan sarana komunikasi yang efektif menyampaikan ide konsep dasar dari model SEM.(Hoyle, 1995) Dalam penelitian ini model dapat digambarkan sebagai berikut:

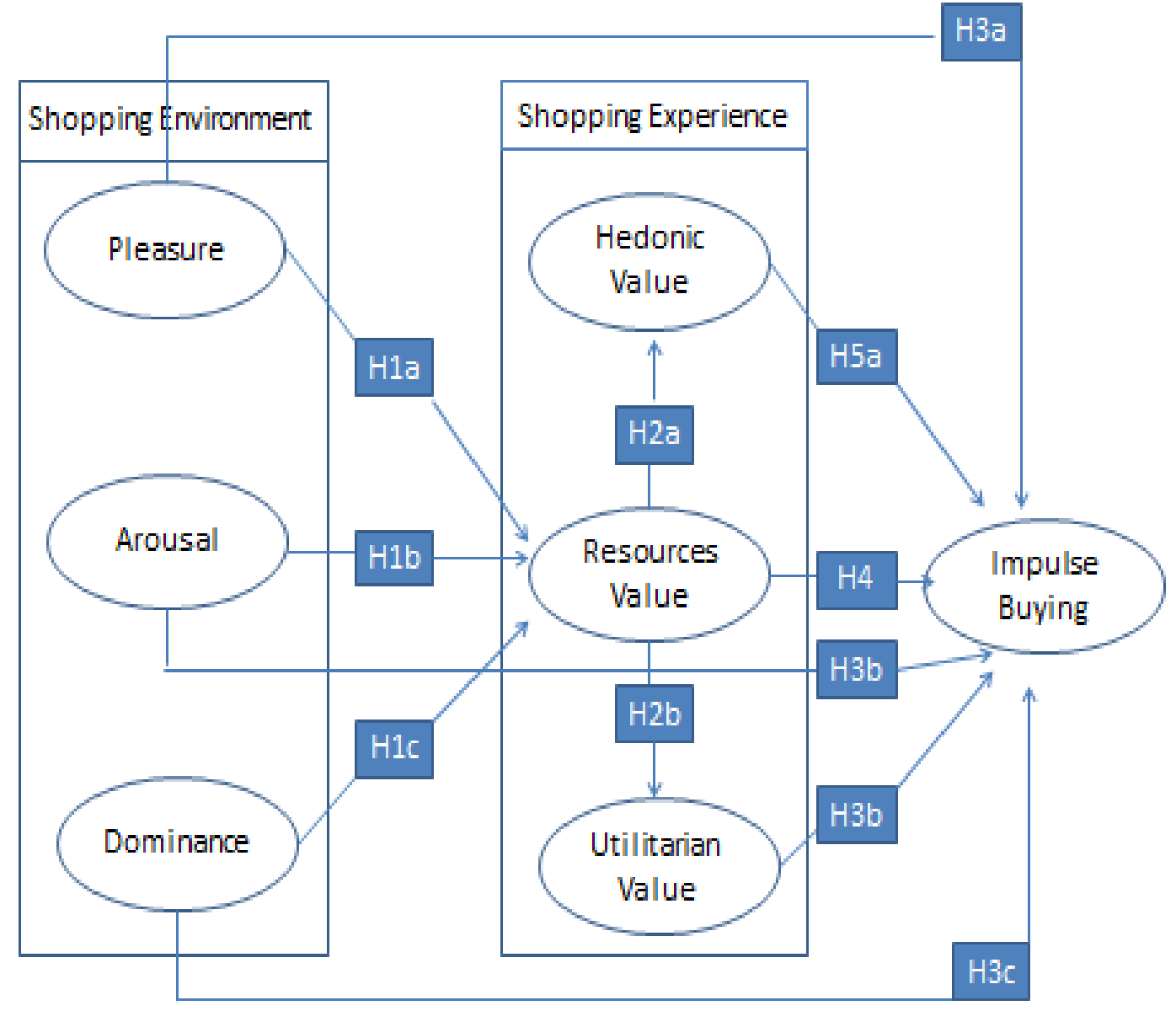

Gambar Model Hipotesis Penelitian antara respon lingkungan belanja(Shopping Environment), Pengalaman Belanja(Shopping Experience) dan Pembelian tidak berencana (Impulse Buying)

\section{Hasil Penelitian}

Penelitian yang dilakukan kepada 60 responden yang berbelanja pada mini market mami mart di dapat bahwa dari status sosial ekonomi $48,3 \%$ mereka berasal dari tingkat pendidikan strata 1 , $75 \%$ tingkat pengeluaran per bulan $>\mathrm{Rp}$ 1.000.000,- dan 28,4\% terdaftar sebagai Pegawai Negeri Sipil di Painan. Sebagai informasi keberadaan mini market $46,7 \%$ menjawab mengetahui dari orang lain dan memilih lokasi sebagai alasan utama berbelanja pada mini market ini.Hasil penelitian mengungkapkan bahwa:

Hipotesis 1a ditolak, Tidak terdapat pengaruh antara perilaku senang (Pleasure) terhadap sumber daya yang dikeluarkan konsumen dalam berbelanja (Resources Expenditure). Menurut Mehrabia dan Russel dalam Samuel (2004) kesenangan (Pleasure) mengacu pada tingkat dimana individu merasa 
baik dan penuh bahagia terkait dengan lingkungan belanja yang dirasakan. Sehingga dengan kesenangan ini merelakan sumber daya dalam bentuk waktu, uang dan harga dalam berbelanja. Namun hipotesis ditolak, dari deskriptif penelitian didapat, sumber daya waktu yang direlakan tidak banyak karena 46,7\% menjawab lokasi mini market dekat dari kantor dan sekolah mereka. 53\% menyatakan karyawan cepat tanggap dalam membantu menemukan barang sehingga mereka tidak lama dalam berbelanja. Namun mereka belum merasakan kesenangan yang ditonjolkan mini market dikarenakan responden ingin cepat dalam berbalanja, bukan berbenja santai.

Hipotesis 1b diterima, Terdapat pengaruh antara gairah belanja konsumen (Arousal) terhadap Resources Expenditure. Hasil analisis deskriptif responden didapat bahwa Konsumen bergairah dengan program promosi penjualan yang dijalankan mini market, adannya diskon berkala pada produk kebutuhan sehari hari dan keinginan kuat dalam mengamati produk yang ditawarkan, Jika keinginan tersebut sudah datang dari diri konsumen sendiri maka konsumen akan merelakan sumber daya mereka yang mereka keluarkan dalam berbelanja seperti Sumber daya harga, waktu dan uang. Kegairahan (Arousal) mengacu pada taingkat dimana seseorang merasa bahagia, digairahkan atau situasi aktif. Kegairahan (Arousal) secara lisan dianggap sebagai laporan konsumen dimana seperti dirangsang, ditentang atau diperlonggar. Mehrabian dan Russel (2004) membatasi kegairahan sebagai sebuah keadaaan perasaan yang secara langsung ditaksir oleh laporan verbal.

Hipotesis 1c diterima, Terdapat pengaruh yang signifikan antara konsumen yang berada pada kekuasaan lingkungan belanja (Dominance) terhadap sumber daya yang dikeluarkan konsumen saat berbelanja (Resources expenditure). Dominasi ditandai dengan respon konsumen yang merasa dikendalikan sebagai lawan mengendalikan, mempengaruhi sebagai lawan dipengaruhi. Pada mini market mami mart kekuasaan dan panduan lingkungan belanja terlihat pada pemberian point of purchaseyang berisi informasi promosi seperti diskon selain itu juga ada kekuasaaan lain seperti musik, tata cahaya, dan aroma khas mini market yang memberikan kemnyamanan pada konsumen untuk lebih betah berada pada lingkungan ini market. Menurut Sunarto (2007:1)tata cahaya mampu mendongkrak penjualan, berkat tata cahaya mudah sekali mempengaruhi persepsi konsumen, karena barang yang biasa bisa terlihat istimewa dengan tata cahaya yang menunjang.

Hipotesis 2a diterima, terdapat pengaruh yang signifikan antara tingkat pengeluaran konsumen sumber daya konsumen untuk berbelanja (Resources Expenditure) Terhadap nilai emosional berbelanja konsumen (Hedonic Shopping Value). Hal ini terlihat dari konsumen merasa senang dengan kegembiraan irama alunan musik yang menemani konsumen dalam berbelanja, tidak hanya itu experientialdibantu dan dipandu oleh sahabat belanja menjadi salah satu alasan enapa konsumen memilih berbelanja. Menurut Goleman dalam Kartajaya (2004:121) otak manusia memiliki dua bagian yakni satu intuk berpikir (Think) dan lainnya untuk merasa (Feel).

Hipotesis 2b diterima, dimana terdapat pengaruh negatif dari tingkat pengeluaran sumber daya konsumen untuk berbelanja(Resources Expenditure) terhadap Utilitarian Shopping Value. Artinya konsumen saat mengeluarkan sumber daya dalam berbelanja sangat mementingkan nilai manfaat dalam belanja tersebut. Alasan konsumen 
berbelanja pada mini market mami mart didominasi oleh alasan akses kemudahan lokasi.lokasi mini market mami mart berada di tengah kota, dekat dengan sekolah, perkantoran dan pemukiman. Selain lokasi dalam berbelanja konsumen juga memperhitungkan waktu berbelanja. Mami mart sangat menghormati konsumen yang terburu-buru, dengan bantuan wiraniaga konsumen dipandu, membantu membawakan keranjang. Pada waktu transakasi terdapat layanan spesial bagi manula dan ibu hami untuk mendapatkan layanan tanpa antrian.

Hipotesis 3a ditolak, terdapat pengaruh langsung secara positif dari konsumen yang berperilaku pleasure terhadap impulse buying. Artinya konsumen dalam penelitian ini dalam melakukan pembelian tidak berencana tidak dipengaruhi oleh kesenangan serta kenyaman pada lingkungan belanja. Menurut Utami (2010:51) faktor yang mempengaruhi pembelian tidak berencana (1) Penggunaan shopping list (2) pemilihan toko seperti lokasi toko, kemudahan transportasi, jam operasional toko, komposisi toko (3) Nuansa Toko seperti desain toko, tata letak, penerangan, warna, musik dan aroma. Namun perbedaan budaya, kelas sosial, dan gaya hidip mampu membuat perbedaan penerimaan mengenai faktor pemicu munculnya pembelian tidak berencana.

Hipotesis 3b ditolak, didapatkan hasil konsumen dalam proses pembelian tidak berencana pada mini market mami mart tidak dipengaruhi oleh gairah belanja seperti promosi yang diberikan. Hal ini sejalan dengan penelitian Samuel (2004) yang menyatakan gairah belanja tidak mempengaruhi pembelian tidak berencana. Responden yang diteliti disominasi oleh PNS yang tidak begitu mementingkan gairah belanja, memiliki tanggal yang pasti dalam melakukan belanja bulananan ditemani oleh shopping list . dari hasil distribusi frekuensi hanya $31,7 \%$ konsumen yang menyukai dengan diskon yang diberikan mini market. Diskon sudah dianggap budaya yang biasa. Seperti yang diungkap Olson (2000:33) menyatakan kandungan suatu budaya adalah kepercayaan, sikap, tujuan dan nilai-nilai yang dipengang oleh sebagian budaya masyarakat dalam suatu lingkungan disamping arti dari perilaku, aturan, kebiasaan, dan norma yang dianut dalam masyarakat.

Hipotesis 3c ditolak, dari hasil analisis penelitian disimpulakan konsumen dalam proses pembelian tidak berencana pada minimarket mami mart painan tidak dipengaruhi oleh kekuasaan lingkungan belanja dalam mempengaruhi dan menuntun konsumen dalam melakukan pembelian tidak berencana. Dominasi kekuasaan lingkungan belanja terlihat belum begitu maksimal. Hanya menempatkan point of purchasesebagai wiraniaga yang bisu, tema yang dimiliki mini market juga belum terlihat jelas. Menurut Sunarto (2010:97) untuk mendorong pembelian impulsif, retail harus memiliki tema selain tema-tema dihari besar. Hal ini bisa dilakukan seperti Go Green, dengan tidak lagi menggunakan plastik sebagai kantong belanjaan melainkan kantong yang bisa didaur ulang.

Hipotesis 4 ditolak, menduga Resources Expendituredapat merupakan mediator dari respon lingkungan belanja dan pengalaman belanja serta berpengaruh negatif terhadap impuse buying. Namun pada penelitian ini didapat hasil bahwa variabel lingkunag belanja seperti kekuasaan lingkungan belanja (Dominance) dan Gairah koinsumen belanja (Arousal) hanya berpengaruh signifikan terhadap sumber daya yang dikeluarkan konsumen untuk berbelanja. Konsumen menganggap lingkunagn belanja yangdinikmati 
sekarang seimbang dengan apa yang telah mereka korbankan demi mendapatkan produk yang diinginkan. Pengorbanan konsumen berupa lokasi mini market yang mudah dijangkau, harga bersaing serta waktu yang lebih efektih dengan bantiuan wiraniaga.

Hipotesis 5a ditolak, hedonic shopping value dapat merupakan variabel mediator antar respon lingkungan belanja dan berpengaruh negatif terhadap impulse buying.nilai kesenangan konsumen dalam berbelanja (hedonic shopping value) membuat konsumen nyaman dan dapat menikamati rekreasi berbelanjanya seperti display yang rapi, lorong yang bersih dan wangi, wiraniaga yang ramah dan membantu, namun kesenangan ini tidak mempengaruhi mereka dalam melakukan tindakan pembelian diluar rencana. Namun untuk mendorong pembelian tidak berencana menurut Sunarto(2010:97) display tidak hanya dituntut untuk tampil rapi namun juga harus sekreatif mungkindalam memadukan warna sehingga terlihat eyecatching

Hipotesis $5 \mathbf{b}$ ditolak, utilitarian Shopping valuedapat merupakan variabel mediator antar respon lingkungan belanja dan berpengaruh positif terhadap impulse buying. Ini sejalan dengan penelitian sebelumnya baik yang dilakukan oleh Samuel (2004), Marlina (2007) dan Aryono (2005). Nilai manfaat produk dalam berbelanja merupakan motivasi konsumen dalam berbelanja apa yang mereka butuhkan saja. Sehingga disaat konsumen datang, yang dituju hanya apa yang mereka rencanakan. Konsumen seperi ini perlu dipengaruhi lebih dalam dengan apa yang mereka anggap spesial dan sesuai namun tetap dianggap bermanfaat bagi mereka. Tipe pembelian tidak terencana pada konsumen dengan memotivasi manfaat belanja seperti ini adalah tipe reminder purchasedimana menurut Utami ( 2007:51) tipe pembelian tidak terencana yang terjadi ketika konsumen melihat produk atau merek tertentu didalam toko dan terinagat bahwa produk atau merek tersebut mereka butuhkan.

\section{PENUTUP}

A. Bagi Produsen produk

Diharapkan dapat memproduksi produk yang memiliki manfaat yang lebih luas untuk memotivasi perilaku pembelian tidak berencana, menyediakan informasi yang mudah dipahami pelanggan seperti transparansi terhadap syarat dan ketentuan yang diberlakukan dalam menetapkan program promosinya dan lebih intensif menggunakan sales pearsonyang berkualitas untuk dapat mempengaruhi pelanggan secara langsung .

B. Pihak manjemen

Memberikan training kepada wiraniaga untuk dapat berkomunikasi pada pelanggan serta memahami item produk, manfaat serta merek kompetitor produk tersebut. Sehingga konsumen diberi banyak alternatif. Dalam kebingungannya konsumen akan menggunakan sisi emosional untuk mendorong terjadinya perilaku pembelian tak berencana. Selain training, manajemen juga harus memabangun komitmen wiraniaganya dengan cara (1) memberikan wewenang sehingga terbentuk distribusi kekuasaan dan wewenang pengambilan keputusan dari manajer ke setiap karyawan (2) membentuk hubungan kesetaraan, tidak ada gap yang berarti antara atasan dan bawahan sehingga akan menghilangkan perbedaan status serta menimbulkan promosi dari dalam.

C. Peneliti selanjutnya

Penelitian membuktikan bahwa secara teoritid terdapat beberapa kondisi yang tidak terpenuhi maupun bertentangan. Sehingga pada peneliti 
selanjutnya perlu ditambahkan faktor budaya, sosial, probadi dan psikologismaupun keterlibatan individu terhadap pengenalan produk sebagai variabel exogenous.

\section{DAFTAR PUSTAKA}

\section{$\underline{10.22202 / \text { economica.2014.v3.i1.238 }}$}

Ahmad, Kamaruddin.1996.Dasar-dasar Manajemen Investasi. Jakarta: PT. RinekaCipta.

2004. Dasardasar ManajemenInvestasi dan Portopolio. Jakarta: PT. Rineka Cipta.

Brigham,Meugne.FdanJoelF.Houston.200 1. Manajemen KeuanganBuku 1. Jakarta: Erlangga. Budiarto,

Arif dan Zaki Baridwan.1999.PengaruhPengu muman Right Issue terhadapTingkatKeuntungan dan Likuiditas Saham Periode 19941996.Jurnal Riset Akuntansi Indonesia

JRAI),Vol.3,No.1,Januari,Page91 -116 .

Fahmi, Irham dan Yovi Lavianti

Hadi.2009. TeoriPortopolio dan

Analisis Investasi.Bandung: Alfa Beta.

Idris. 2006.AplikasiModelAnalisisData

KuantitatifDengan Program SPSS. Padang. FakultasEkonomi
UNP.

Jogiyanto.2003.TeoriPortofolio dan Analisis Investasi, Edisi Ketiga. Yogyakarta:BPFE.

Samsul, Mohammad. 2006.Pasar Modal dan Manajemen Portofolio. Jakarta: Erlangga.

Siswanto, Heri. 1999. Studi Empiris tentang Pengaruh Pengumuman Right Issue terhadap Tingkat Keuntungan dan Likuiditas Saham Di Bursa EfekJakarta Periode1997-1999. Jurnal ekonomika

Solichin, Agus dan Imam Ghozali.2003.

AnalisisDampak Pengumuman Right IssueTerhadap Reaksi PasardiBursaEfek Jakarta. Jurnal Ekonomi Perusahaan (JEP),Vol.10,No.1,Maret,Page100 $-114$.

Sartono, Agus. 2001.Manajemen Keuangan Teori dan Aplikasi. Yogyakarta: BPFE-Yogyakarta

Sunyoto. 2001. Pengaruh Emisi Right Issue terhadapAbnormalReturn danVolume PerdaganganSaham $d i \quad B E J$,Tesis S2 UNDIPyang dipublikasikan. Semarang.

Tandelilin, Eduardus. 2001.Analisis investasidan manajemen portopolio. Yogyakarta : BPFE Yogyakarta.

Tjiptono, Darmaji dan Fakhrudin Hendy M. 2001. Pasar Modal di IndonesiaEdisil.Jakarta SalembaEmpat. 